\title{
OVERVIEW OF CRITERIA FOR INTERIM WET \& DRY STORAGE OF RESEARCH REACTOR SPENT NUCLEAR FUEL
}

\author{
R.L. Sindelar, D.W. Vinson, N.C. Iyer, and D.L. Fisher \\ Savannah River National Laboratory, Aiken SC
}

\begin{abstract}
Following discharge from research reactors, spent nuclear fuel may be stored "wet” in water pools or basins, or it may be stored "dry" in various configurations including non-sealed or sealed containers until retrieved for ultimate disposition. Interim safe storage practices are based on avoiding degradation to the fuel that would impact functions related to safety. Recommended practices including environmental controls with technical bases, are outlined for wet storage and dry storage of aluminum-clad, aluminum-based research reactor fuel.

For wet storage, water quality must be maintained to minimize corrosion degradation of aluminum fuel. For dry storage, vented canister storage of aluminum fuel readily provides a safe storage configuration. For sealed dry storage, drying must be performed so as to minimize water that would cause additional corrosion and hydrogen generation. Consideration must also be given to the potential for radiolytically-generated hydrogen from the bound water in the attendant oxyhydroxides on aluminum fuel from reactor operation for dry storage systems.
\end{abstract}

\section{INTRODUCTION}

The design for most research reactor fuel is an aluminum-based fuel matrix that is clad with an aluminum alloy [1]. There are important considerations however in the use of aluminium and aluminium alloy claddings for reactor fuel during reactor operation, and especially in post-reactor fuel storage. Aluminium alloys show very different oxidation behaviour from fuels produced with stainless steel and Zircaloy claddings. For example, during reactor operation, aluminium claddings can develop relatively thick oxide layers [2] that are subject to spallation [3]. Also, aluminum fuel is particularly susceptible to corrosion degradation in water, particularly if the quality of the water is poor [4].

After discharge from the reactor and initial cooling in a water pool, nuclear fuel may be continued to be stored "wet" in an at-reactor (AR) pool, or in away-from-reactor (AFR) pool facility, or it may be placed in dry storage. Interim storage of spent nuclear fuel in these two types of storage systems, even for short time (e.g. less than 1 year), must consider potential degradation mechanisms in preparing the fuel for storage and the storage environment. The overall objectives for a fuel storage system are to 1) maintain degradation of the fuel within acceptable limits; and 2) minimize degradation of the storage system itself to meet the mission needs for interim spent nuclear fuel storage.

This paper provides a summary of recommended storage practices including scientifically-based criteria or controls to environments of storage so as to avoid significant degradation of the fuel. The 
practices are focussed on aluminium-clad, aluminium-based fuel in wet and in dry storage systems. The practices to avoid significant degradation of the storage system materials are not addressed in this paper.

\section{CRITERIA FOR STORAGE}

Storage criteria are defined as the set of practices that are needed, including environmental controls, to limit the fuel materials' degradation during storage. Fuel degradation can impact both safety functions and the fuel condition assumed for its ultimate disposition.

\section{Fuel Degradation Impacts to Safety Functions in a Fuel Storage System}

The change in fuel condition during preparation for, and during the storage period, should be limited to avoid adverse impacts to:

- criticality safety;

- general containment by the fuel/(clad system ${ }^{1}$

- the ability to retrieve the fuel; and

- options for ultimate disposition

An understanding of requirements for each of these functions is important to identify limits to fuel degradation in storage. For example, corrosion of the fuel that causes extensive damage to its structure may challenge the ability to grasp and handle the fuel with tools.

\section{Limits to Fuel Degradation in Storage}

Degradation of spent nuclear fuel in storage systems may include one or more of the following phenomena:

- a loss in net section of cladding through cracking, pitting, or general thinning;

- embrittlement of the fuel/clad structure;

- distortion of physical shape (sometimes termed "geometry") of the fuel;

- diffusion of fuel or fission products through the cladding;

- diffusion of volatile fission products through the fuel matrix (in fuel that may have breached cladding); and

- alteration of the fuel due to chemical reactions (e.g. oxidation at breaches in cladding)

Except for embrittlement of the fuel/clad structure that is a result of operation of the fuel in the reactor, each of the other degradation phenomena can be limited by storage practices including controls to the environments of storage. General practices, with the underlying technical bases, for wet storage and dry storage systems are described in the following sections. The specific practices for a specific design of a storage system could be developed from these general practices.

\footnotetext{
${ }^{1}$ In many interim storage systems, the cladding is not typically credited to provide confinement in the safety basis. Nevertheless, large breaches may cause undesired gross release of radioactivity, and for this reason, general containment provided by the fuel/clad system in interim should be maintained.
} 


\section{Wet Storage Criteria for Aluminum Spent Nuclear Fuel}

Corrosion attack of the aluminum claddings is the primary degradation phenomena for aluminum fuel in wet storage. The types of corrosion that can cause significant attack to aluminum alloys in water are listed in Table 1. Of these types, pitting, crevice, galvanic, sediment-induced, and filiform corrosion are the most prevalent for aluminum fuels in wet storage $[4,5]$.

Table 1. Corrosion types for fuel in water storage

General Corrosion
Pitting Corrosion
Crevice Corrosion
Galvanic Corrosion
Intergranular Corrosion
Stress Corrosion Cracking
End-Grain Attack
Erosion-Corrosion
Blister Formation (Filiform Corrosion)
Microbial Corrosion
Sediment-Induced Corrosion

As an example of corrosion attack to aluminum fuel, Figure 1 shows filiform corrosion that occurred in an assembly stored in poor water quality conditions [6]. Photographs of corrosion damage of several of the other types of corrosion are contained in figures in reference 5 .
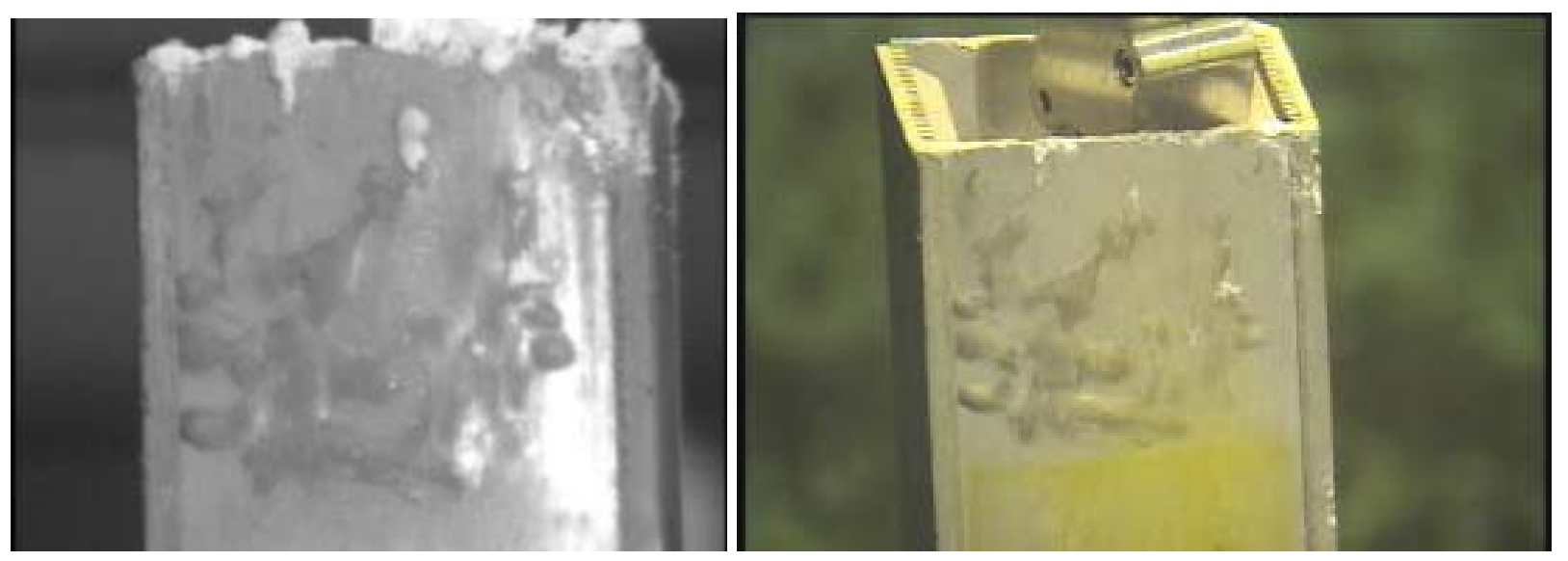

Figure 1. Filiform corrosion causing blister formation in the outer aluminum fuel plate of an MTR design fuel assembly stored in poor water quality. Figure 1A (left photograph) is an above-water photograph taken at the original fuel storage site. Figure 1B (right photograph) is an under-water photograph of the same fuel assembly taken at the Savannah River Site, the present storage location. [Figures reproduced from reference 6].

The only plausible degradation of the fuel in wet storage significant to impact the safety functions of containment by the fuel/clad system and ability to easily retrieve the fuel, is that caused by 
corrosion. Corrosion of aluminum alloys can be minimized with controls of water quality and avoidance of crevices and galvanic couples with the fuel and storage system materials. Water quality is defined by a set of parameters that are used to characterize the water physical and chemical conditions. It includes $\mathrm{pH}$; conductivity; dissolved impurity species; undissolved solids; colloids; organic substances; biological organisms; and temperature.

The recommended practices for wet storage of aluminum spent nuclear fuel, including the set of ranges and/or limits for the physical and chemical parameters of water quality, is contained in reference [5]. The document also includes a detailed review of the corrosion of aluminum in water and the technical bases for the practices of wet storage of the fuel.

An important consideration is the initial condition of the fuel that would be placed in a wet storage system. Even breached fuel can be safely stored in a basin with active water clean-up systems. However, if significantly damaged with excessive leaking of radioactivity and loss of ability to easily handle and move the fuel, the fuel can be stored underwater in isolation canisters. These management practices for breached and damaged fuel are discussed in a companion paper [7].

\section{Dry Storage Criteria for Aluminum Spent Nuclear Fuel}

An evaluation of mechanisms that could degrade aluminum fuel for a range of dry storage environments and impact the safety functions for storage is contained in references 8 and 9, and is summarized here. Limits to the amount of fuel degradation (e.g. loss of cladding net section due to corrosion; fuel distortion due to creep) are coupled to limits for the environments of storage (e.g. air; temperature, water vapor). The limits to the environmental conditions were also developed as candidate acceptance criteria for a 50-year dry storage period for the aluminum fuel in references 8 and 9.

The fuel temperature in a dry system would be higher than in wet storage due to removal of water as a cooling media and consolidation of fuel to reduce the footprint of a storage system. Potential degradation modes of the aluminum fuel due to thermal processes only are distortion due to creep and diffusion of radionuclides through the cladding. In addition, the cladding is embrittled due to its irradiation in the reactor.

An evaluation of fuel distortion due to creep was previously reported [10]. Figure 2 shows the fuel plate model, and the results of finite element analysis under Coble creep deformation for temperatures from $150-250^{\circ} \mathrm{C}$ for a 50 -year period for several assumed grain sizes for aluminum. Creep rupture of the cladding is not expected due to the high ductility of annealed aluminum. However, excessive distortion would be expected to impact the ability to remove the fuel from the storage system, and a limit of $200^{\circ} \mathrm{C}$ was specified [8] to avoid a deflection of $2.5 \mathrm{~mm}$ due to fuel plate slump due to creep for a 50-year period. Fuel and storage system-specific designs should be evaluated to avoid high fuel temperatures that would cause excessive creep for the planned storage period. 

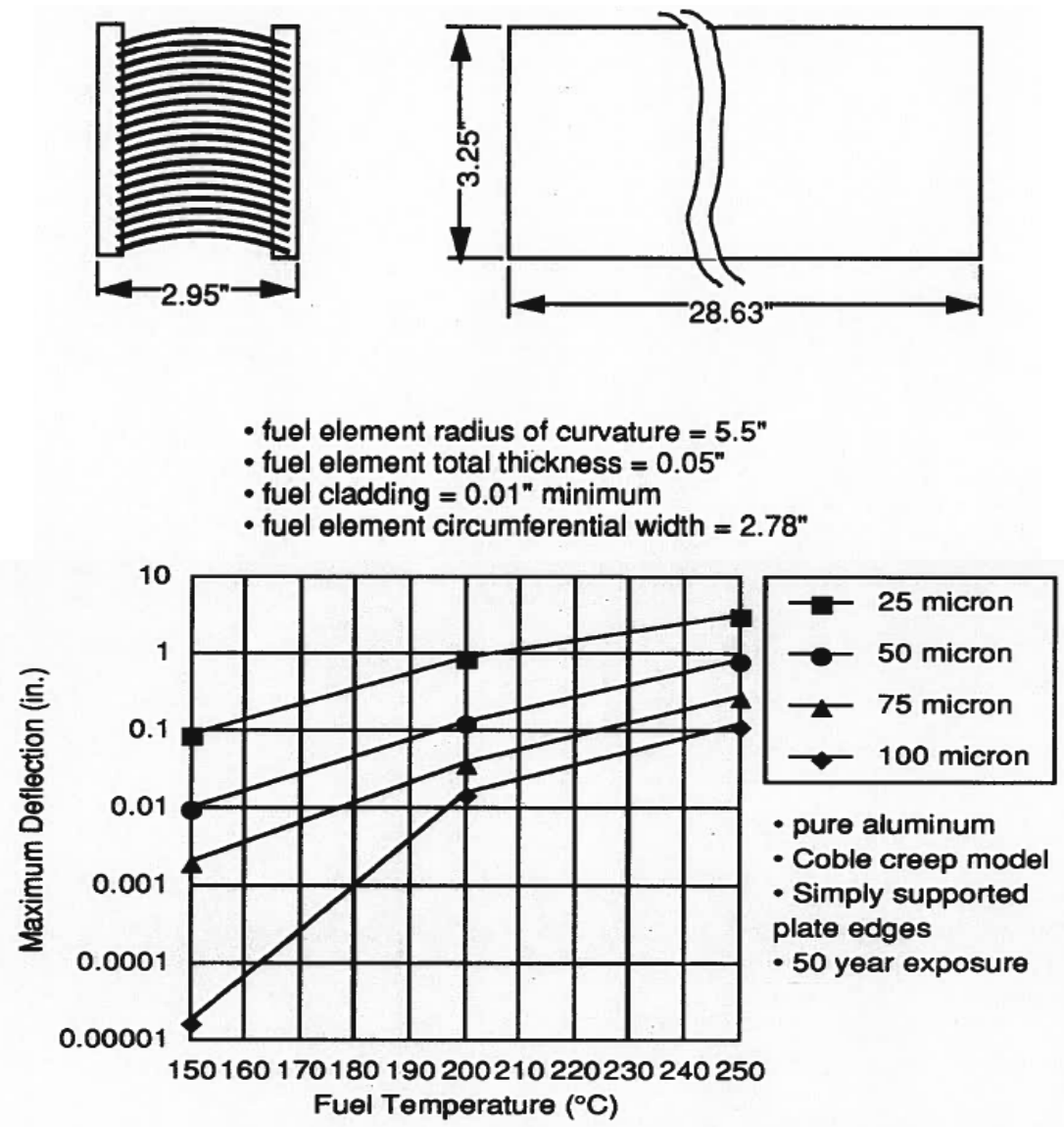

Figure 2. Maximum vertical deflection of a single fuel plate after 50 years at temperature. Average grain sizes for the aluminum are indicated in the legend [figure reproduced from reference 10]

The diffusion of fission products, actinides, and uranium through the aluminum cladding impacts leachability of the fuels and would result in a release of radioactivity if corrosion of the cladding would occur following the through-clad diffusion of the radioisotopes. Diffusion of radionuclides from the fuel through the aluminum cladding was also previously reported [9]. Using the metrics of [11]:

Time to breakthrough $=0.06 \mathrm{l}^{2} / \mathrm{D}$ and

Time to steady state $=0.451^{2} / \mathrm{D}$,

where $\mathrm{D}$ is the diffusivity $\left(\mathrm{cm}^{2} / \mathrm{sec}\right)$ and $\mathrm{l}$ is the cladding thickness $(\mathrm{cm})$, the results show breakthrough of $\mathrm{Cs}$ and $\mathrm{U}$ through an assumed $0.76 \mathrm{~mm}$ thick aluminum cladding in 50 years at a temperature of approximately $250^{\circ} \mathrm{C}$.

Aluminum cladding alloys are embrittled following exposure to a fast $\left(E_{n}>0.1 \mathrm{MeV}\right)$ neutron fluence above approximately $1 \times 10^{19} \mathrm{n} / \mathrm{cm}^{2}$. This condition is typical for the spent fuel. The tensile ductility as measured by total and uniform strain of irradiated 1100 and 6061 aluminum reduces to less than $5 \%$ and $1 \%$, respectively, between 150 and $200^{\circ} \mathrm{C}$ [12]. No gross leakage of 
radioactivity would be expected even if cracking due to excessive strains did occur since the fuel core remains metallurgically-bonded with the cladding even at high burnup (See Figure 3)

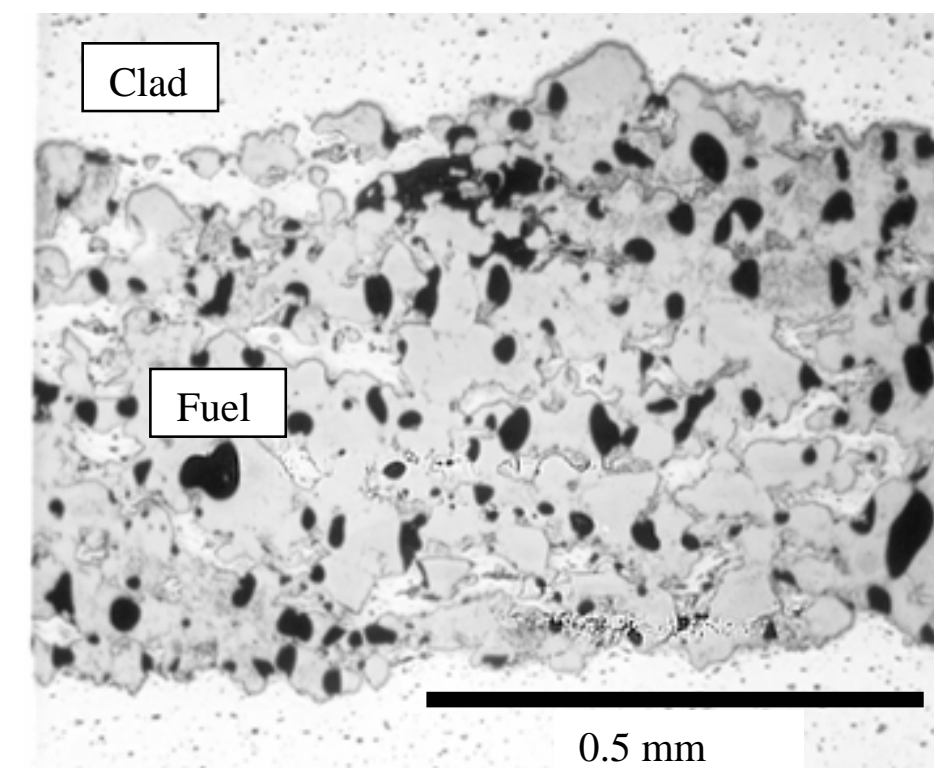

Figure 3. Cross-section of aluminum-clad, $\mathrm{UAl}_{\mathrm{x}}-\mathrm{Al}$ fuel irradiation to $>50 \%$ burnup

Two distinct types of dry storage systems are envisioned: a "sealed system” which would store fuel assemblies in fully-sealed containers and a "non-sealed" system which would store assemblies in non-sealed containers or holders open to the environment of the facility.

\section{Sealed Dry Storage}

The approach to avoid excessive degradation in a sealed system is to dry the contents of water remaining in the fuel/container to-be-sealed, for both free and bound waters, to a level such that if the water is consumed by corrosion of the fuel, acceptable degradation of the fuel is maintained; and also that the production of hydrogen does not pose a threat. Gases produced may overpressure containers, embrittle materials, reach flammable concentrations, accelerate corrosion, or form pyrophoric species that would impact safe post-storage retrieval. As an example, rapid corrosion attack can occur with a combination of air, water, and the attendant radiation of a fuel.

A large set of vapor corrosion tests were performed for several cladding alloys and uraniumaluminum alloys to evaluate the corrosion response for temperatures up to $200^{\circ} \mathrm{C}$ and relative humidities up to $100 \%$ [13]. Boehmite is the predominant oxide that forms at temperatures above approximately $80^{\circ} \mathrm{C}[14]$ in accordance with:

$$
4 \mathrm{H}_{2} \mathrm{O}+2 \mathrm{Al}=\mathrm{A}_{2} \mathrm{O}_{3} \cdot \mathrm{H}_{2} \mathrm{O}+3 \mathrm{H}_{2}
$$

The growth of a coherent passive hydrated oxide film under water vapor conditions, with concurrent metal consumption can be modeled with a mechanistically-based, phenomenological model given by [13]:

$$
\Delta \mathrm{w} \text {, oxide thickness, metal loss }=\mathrm{Ae}^{(-\mathrm{Qn} / \mathrm{RT})} \operatorname{time}^{\mathrm{n}}
$$


where $\Delta \mathrm{w}$ is the weight gain of a specimen which is proportional to the average oxide thickness on the specimen, and also to the metal consumed in the corrosion reaction. ${ }^{2}$ In general, the parameter $\mathrm{A}$ is a function of alloy composition, cover gas, water vapor composition, and relative humidity (RH). The activation energy $\mathrm{Q}$ is a function of alloy composition and $\mathrm{n}$ is a function of alloy composition, and water vapor composition.

Further tests were performed in which aluminum cladding alloys were placed in a sealed capsule with air and water and placed in a gamma cell [13]. The results showed that rapid corrosion occurred relative to the cases with no radiation as shown in Figure 4. In addition, corrosion occurred at all values of relative humidity, that is, there was no threshold in $\mathrm{RH}$ for corrosion to occur as compared to the case (not shown in figure 4) with no radiation. The mechanism of the attack was attributed to a lowering of the $\mathrm{pH}$ of the water by radiolysis of the air. Additional information on impact of radiolysis on corrosion of aluminum in vapor/air environments is reported in reference [15].

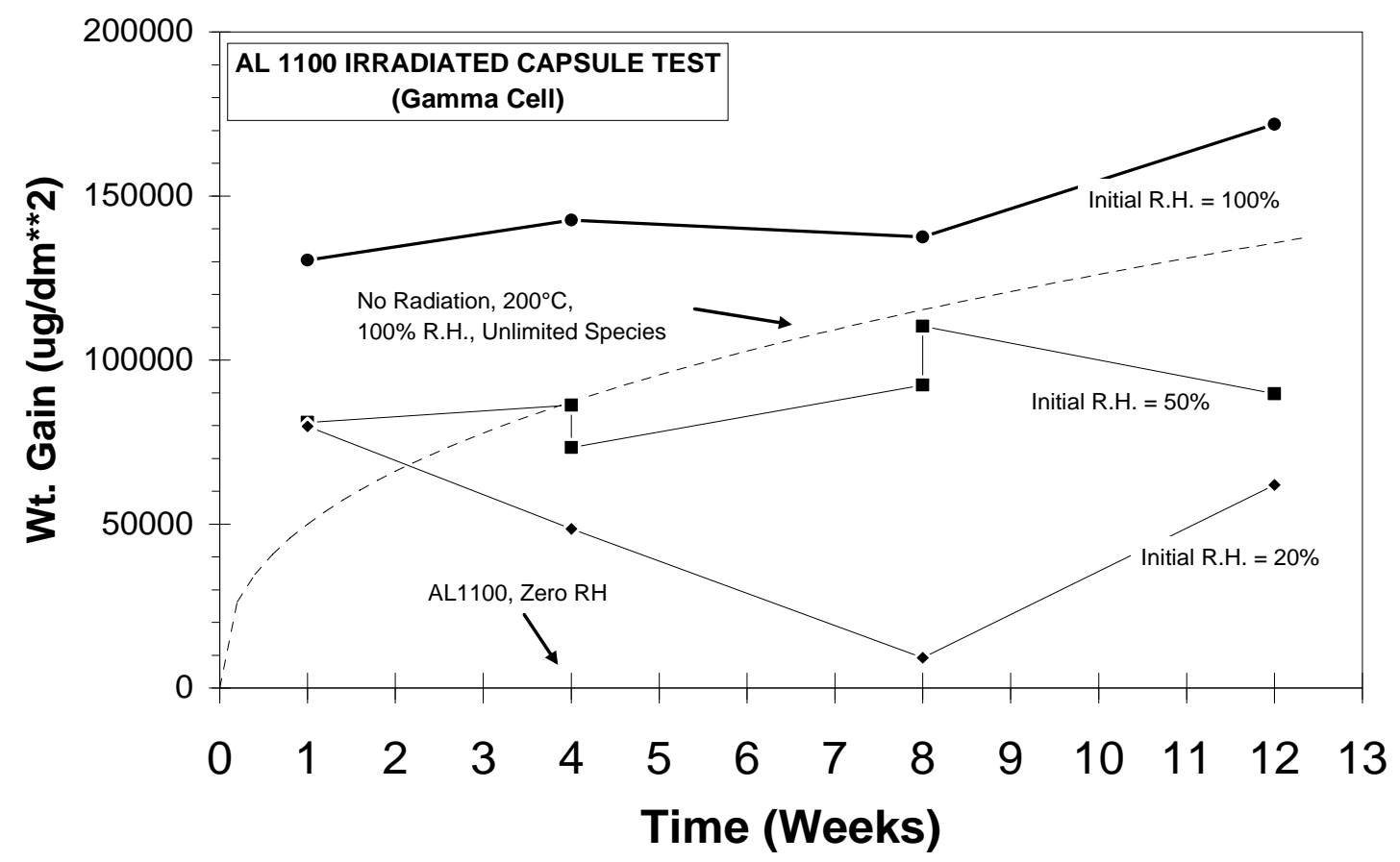

Figure 4. Kinetics of vapor corrosion of aluminum 1100 under air and water vapor exposure under gamma $\left({ }^{60} \mathrm{Co}\right)$ radiation at $1 \mathrm{E} 4 \mathrm{~Gy} / \mathrm{hr}$ [figure reproduced from reference 13 ]. The water vapor in the capsule tests was limited and was effectively consumed by 1 week of exposure.

Aluminum fuel may be exposed to the environment through cladding breaches. Tests of the corrosion of uranium-aluminum alloys in dry air [16] and under water vapor conditions [13] have been reported. Figure 5 shows the results of testing non-irradiated aluminum-10\% uranium and

\footnotetext{
${ }^{2}$ For Boehmite growth on aluminum: Metal Loss $(\mathrm{mm})=3.030 \times 10^{-8} \mathrm{x}$ Wt. Gain $(\mu \mathrm{g} / \mathrm{dm} 2)$; Oxide Film Thickness (Boehmite film in nm) $=0.0533319$ x Wt. Gain $(\mu \mathrm{g} / \mathrm{dm} 2)$
} 
aluminum- $18 \%$ uranium in saturated water vapor at $200^{\circ} \mathrm{C}$ in comparison to 1100 aluminum. The formation of a passivating oxyhydroxide film on aluminum-uranium alloys limits its corrosion with time, similar to the pure aluminum cladding alloy 1100. Furthermore, no significant galvanic couple between the aluminum 1100 and the aluminum-uranium $\left(\mathrm{Al}-\mathrm{UAl}_{\mathrm{x}}\right)$ alloy materials in pure water was observed [13]. Similar behavior is expected for the other aluminum-based dispersoid fuel (e.g., $\mathrm{U}_{3} \mathrm{Si}_{2}$-aluminum and $\mathrm{U}_{3} \mathrm{O}_{8}$-aluminum).

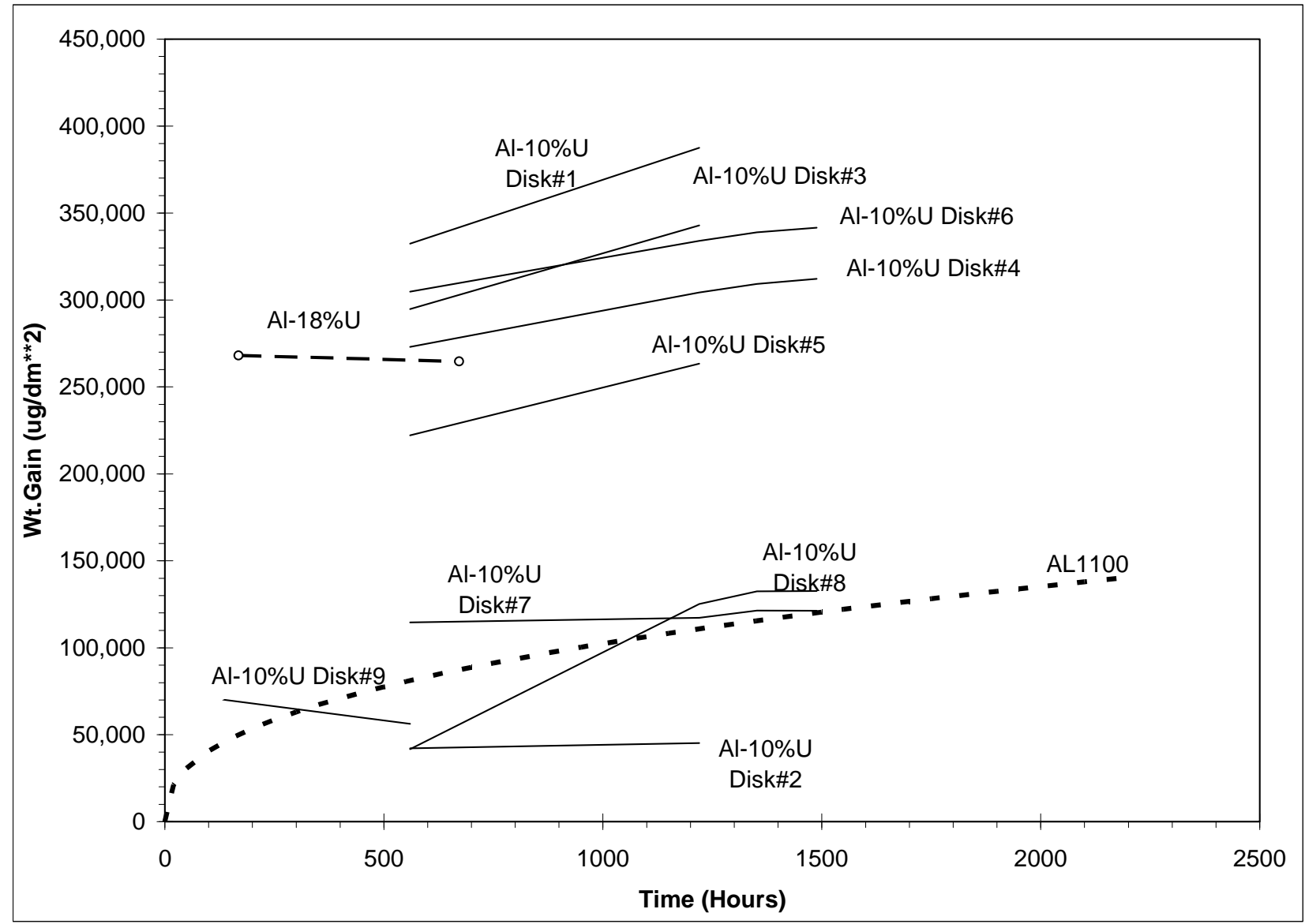

Figure 5. Weight gain of aluminum and aluminum-uranium alloys in water vapor at $200^{\circ} \mathrm{C}$ [figure reproduced from reference 13]

Another phenomenon that is expected to occur is radiolysis of the oxyhydroxides on the fuel to generate hydrogen gas. Exposure of oxyhrodroxides of aluminum, present on spent fuel, to gamma irradiation can produce radiolytic hydrogen gas [17]. Tests of pure Bayerite and Boehmite powders in both fully-dried and with water absorbed from humid air conditions were investigated in initial work [17]. The oxides were in typical fine crystalline form (as powders) and were prepared under several conditions including particle size, and "dry" (without physisorbed and chemisorbed water) vs. "wet" conditions. The specific purpose of exposing these oxides to gamma radiation was to quantify hydrogen production under Argon cover gas in a closed stainless steel container. Other species were also quantified (e.g. $\mathrm{H}_{2} \mathrm{O}, \mathrm{O}_{2}$ ). 
Sealed containers contained gibbsite $\left(\mathrm{Al}_{2} \mathrm{O}_{3} \bullet 3 \mathrm{H}_{2} \mathrm{O}\right)$ and boehmite $\left(\mathrm{Al}_{2} \mathrm{O}_{3} \bullet \mathrm{H}_{2} \mathrm{O}\right)$ powders prior to placement in the gamma irradiator. The powders were procured in powder form, with particles ranging up to 100 microns in size. Ten grams of both compounds were stripped of adsorbed water by oven drying at $60^{\circ} \mathrm{C}$ (no chemically bound water was removed) before loading the test vessels. In two samples, the air was dry and in two, the air was saturated. Two blanks were also tested, one with air over 10 grams of deionized water, and one with dry atmospheric air only. The samples were placed in a Shepherd 109-08 gamma cell with a cobalt source and irradiated at $5 \times 10^{5} \mathrm{R} /$ hour for 168 hours. The gas was analyzed in a Pfeiffer GAM400 mass spectrometer. Measurable quantities of hydrogen were generated from the dry and the moist Boehmite while the Gibbsite produced little or no measurable hydrogen. Figure 6 shows the results of hydrogen that evolved from the materials.

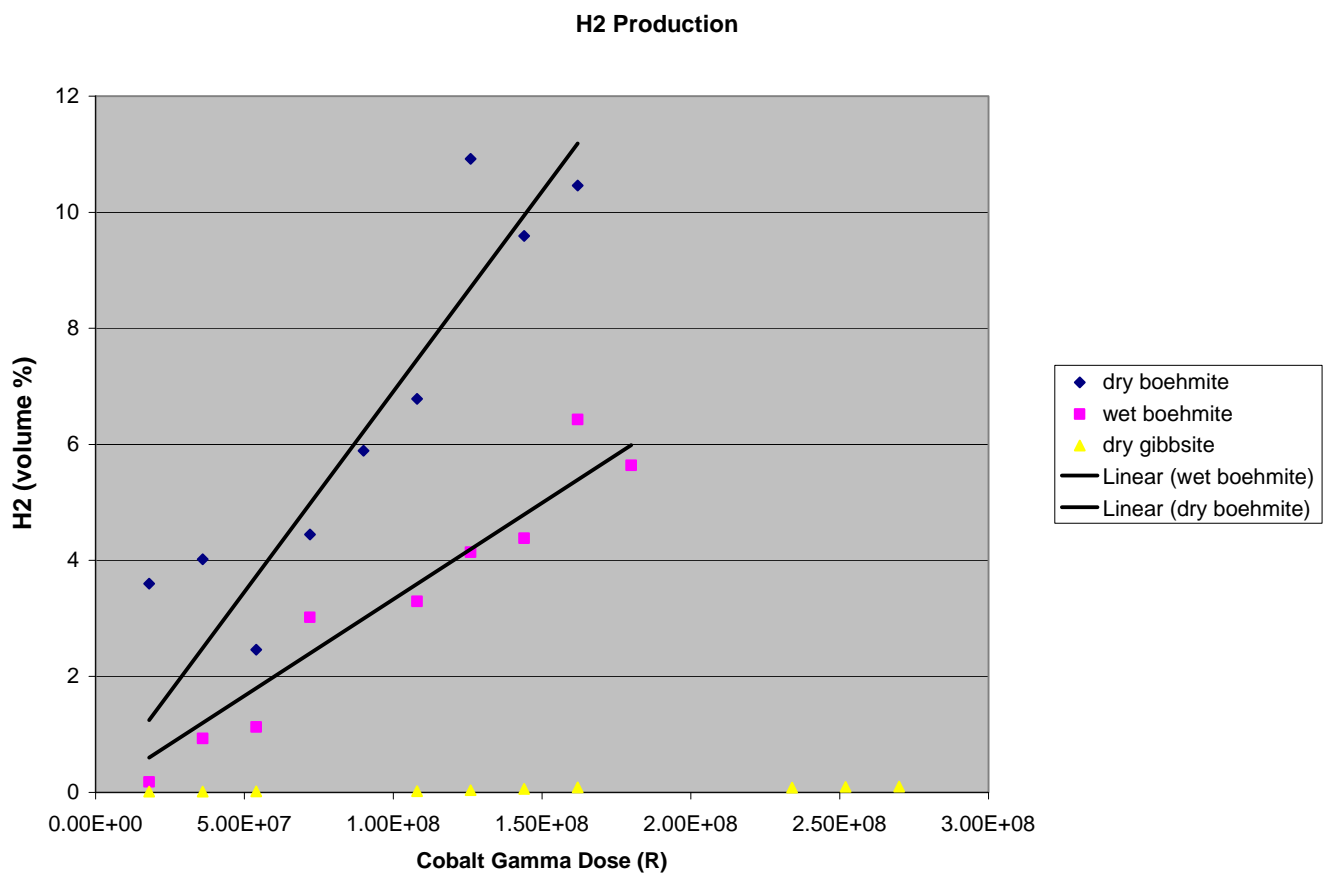

Figure 6. Evolved hydrogen from gamma irradiation of aluminum oxyhydroxides [reproduced from reference 17]

\section{Non-sealed Dry Storage}

A non-sealed system is one in which fuel would be in contact with the ambient air in a dry storage facility (e.g. outside air temperature and relative humidity conditions). Since the corrosion of aluminum exposed to ambient air progresses at a slow rate, even at high humidities (up to 100\%) at near room temperatures, safe storage in a non-sealed system can be achieved. One caution is nonsealed storage in "dirty" atmospheres (those containing low chloride and sulphate compounds). A non-sealed system would also be subject to demonstration of confinement in storage of breached fuel. 


\section{Drying Criteria}

If water remains with the fuel/canister configuration, material interactions may result in fuel corrosion damage, fuel container corrosion damage, criticality safety issues, generation of flammable gases (hydrogen), or formation of pyrophoric species (uranium hydride). As noted, water is of particular concern in sealed fuel storage containers.

To limit these issues in both vented dry storage and, imperative for sealed dry storage, it is important to remove the attendant water from the fuel to the extent practicable. The total amount of water associated with a spent fuel and canister system are from three basic sources. These are: 1) free water (which includes water in pits in the cladding, crevices, etc.; 2) waters of hydration on existing oxyhydroxides; and 3) adsorbed waters on oxyhydroxides and on aluminum metal and other materials in the system. General guidelines for drying of spent fuel to remove these waters have been developed [18].

A specific time-temperature recipe for use in a drying system for a fuel is highly dependent on the following factors:

- fuel configuration (e.g. plate fuel with crevices);

- fuel condition (e.g. fuel with various oxyhydroxides of various thickness containing chemically-bound and adsorbed waters); and

- features of the fuel-in-canister system to be dried (e.g. debris on fuel, configuration of the fuel/canister).

\section{Drying for Non-sealed Storage Systems}

Free water removal to avoid extensive corrosion (e.g. that would occur if aluminum fuel were to be in a canister with bulk free water) is the primary concern for non-sealed storage systems. Any hydrogen generation from corrosion or radiolytic reactions with the bound water in the oxyhydroxides would be vented.

A Fuel Drying Station has been developed [19] and is in use at INTEC is used for aluminum spent fuel to remove free water [20]. The aluminum fuel being stored at INTEC in the Irradiated Fuel Storage Facility in CPP-603 is in a vented (non-sealed) dry storage system to mitigate potential issue with potential gas generation. Aluminum spent fuel has also been dry stored in other countries including Canada and Australia [21].

\section{Drying for Sealed Storage Systems}

For sealed storage systems, a drying requirement for interim dry storage is based on avoiding hydrogen gas, $\mathrm{H}_{2}$, build-up during storage in sealed canister. $\mathrm{H}_{2}$ is generated through both corrosion reactions with water and through radiolytic reactions of radiation with oxyhydroxides.

Assuming the reaction goes to completion, $1 \mathrm{ml}$ of $\mathrm{H}_{2} \mathrm{O}$ yields 0.042 moles of $\mathrm{H}_{2}$. The generation of hydrogen in the above mentioned reaction to produce $\mathrm{Al}_{2} \mathrm{O}_{3} \cdot \mathrm{H}_{2} \mathrm{O}$ bounds that for the reaction to produce $\mathrm{Al}_{2} \mathrm{O}_{3} \cdot 3 \mathrm{H}_{2} \mathrm{O}$ that occurs at temperatures below approximately $80^{\circ} \mathrm{C}$. Relationships have been developed to relate the volume fraction of free water to the hydrogen pressure in a sealed canister volume for the reaction at completion [8]. 
Another impact of hydrogen buildup is the potential for production of $\mathrm{UH}_{3}$, a compound that is pyrophoric under certain conditions. Dispersoids such as $\mathrm{UAl}_{\mathrm{x}}$ would not be reduced by expected hydrogen pressures to produce $\mathrm{UH}_{3}$; however, oxides of uranium could be if the partial pressure of $\mathrm{H}_{2} \mathrm{O}$ is low enough and the partial pressure of $\mathrm{H}_{2}$ is high enough in an $\mathrm{H}_{2} \mathrm{O} / \mathrm{H}_{2}$ system. However, because aluminum surrounds the oxides in the dispersoid fuel and does not allow direct contact with the fuel particles, this is not expected to result in significant production of $\mathrm{UH}_{3}$.

Considering the potential for existing $\mathrm{UH}_{3}$ on uranium metal fuels retrieved from basin storage, only uranium metal fuels may need to be stabilized. A stabilization treatment with the technical bases has been developed [22] to convert $\mathrm{UH}_{3}$ to uranium oxide. No significant amount of $\mathrm{UH}_{3}$ is expected to be present on aluminum-based fuels. In addition, the stringent drying requirements ensure that the expected $\mathrm{H}_{2}$ build-up is extremely low so that $\mathrm{UH}_{3}$ production due to $\mathrm{H}_{2}$ gas contacting exposed fuel meat is negligible.

It is also important in drying aluminum spent fuel to avoid very high drying temperatures. The drying temperature should not exceed $\sim 250^{\circ} \mathrm{C}$ to avoid the potential for hydrogen blistering and gross cladding failure.

\section{CONCLUSIONS}

Planning, development, and implementation of a system for final disposition of the spent nuclear fuel from many research reactor sites are not likely to be completed in near future. Wet and dry storage systems can be used for storage in the interim, with the imperative to limit fuel degradation during storage to enable its safe storage and retrieval for its ultimate disposition path. Aluminum spent nuclear fuel poses challenges in interim storage primarily due to it susceptibility to corrosion and related degradation phenomena.

For wet storage, the corrosion of aluminum can be minimized with controls for water quality and elimination of crevice conditions, stagnant water conditions, and galvanic couple conditions in the fuel storage system.

For dry storage, vented storage would allow for incomplete drying including discounting the presence of oxyhydroxide films on aluminum that contain chemically-bound water. For sealed dry storage, consideration must be given to sufficiently dry the fuel to avoid additional corrosion with concomitant hydrogen generation and the impact on canister pressurization and ability for safe retrieval. Initial work has also indicated that hydrogen can be generated from the oxyhydroxides.

In the absence of corrosion-related phenomena, at high fuel temperatures (e.g. $>200^{\circ} \mathrm{C}$ for a 50 year storage period) fuel deformation due to creep may become significant to impact retrievability.

Continued storage that provides full retrievability for long term storage (e.g. $>50$ years) will require vigilance in maintaining environmental limits of acceptable storage. Continued surveillance and evaluation of the fuel and storage system materials to verify the predicted impact of the environment on materials behavior would also be needed to demonstrate reliable safe storage throughout the storage period. 


\section{REFERENCES}

[1] INTERNATIONAL ATOMIC ENERGY AGENCY, Research Reactor Database (RRDB), http://www.iaea.org/worldatom/rrdb/

[2] KIM, Y.S., G.L. Hofman, J. Rest, A.B. Robinson, Oxidation of Aluminium Alloy Cladding for Research and Test Reactor Fuel, Journal of Nuclear Materials, Volume 378, Issue 2, 31 August 2008, Pages 220-228

[3] PAWEL, R.E., et al., The Corrosion of 6061 Aluminum under Heat Transfer Conditions in the ANS Corrosion Test Loop, Oxidation of Metals 36 (1/2) (1991) 175.

[4] INTERNATIONAL ATOMIC ENERGY AGENCY, Corrosion of Research Reactor Aluminum Clad Spent Fuel in Water, IAEA-TRS-418, IAEA, Vienna (2003).

[5] INTERNATIONAL ATOMIC ENERGY AGENCY, "Recommended practices for water quality management in research reactors \& spent fuel storage facilities,” IAEA Nuclear Energy Series, to be published 2010.

[6] ANDES, T.C., W.S. Large, R.B. Castle, M.R. Louthan, V.S. Valdes, and R.L. Sindelar, "Characterization of Corrosion Damage of Aluminum Fuel Assemblies in Basin Storage,” American Nuclear Society Fifth Topical Meeting - DOE Spent Nuclear Fuel and Fissile Materials Management, September 23-27, 2002, Charleston, SC.

[7] VINSON, D.W., R.L. Sindelar, R.W. Deible, N.C. Iyer, and M.D. Shaffer, "U.S. Practice for Interim Wet Storage of RRSNF,” proceedings of IAEA Technical Meeting, Thurso, Scotland, October 19, 2009.

[8] SINDELAR, R.L., H.B. Peacock, Jr., P.-S. Lam, N.C. Iyer, and M.R. Louthan, Jr., “Acceptance Criteria for Interim Dry Storage of Aluminum-Alloy Clad Spent Nuclear Fuels (U) Fuels, Westinghouse Savannah River Company Report WSRC-TR-95-0347, March 1996.

[9] SINDELAR, R.L., H.B. Peacock, Jr., P.S. Lam, N.C. Iyer, and M.R. Louthan, Jr., "Scientific Basis for Storage Criteria for Interim Dry Storage of Aluminum-Clad Fuels," proceedings of Symposium on the Scientific Basis for Nuclear Waste Management XIX, Boston, MA, November 27 - December 1, 1995, published by the Materials Research Society, 1996

[10] MILLER, R.F. and R.L. Sindelar , "Creep Analysis For Materials Test Reactor Fuel Assemblies In Dry Storage (U);" WSRC-TR-95-00121; 3/16/1995, Westinghouse Savannah River Company report.

[11] SHEWMON, P., Diffusion in Solids, Wiley; 2 edition (October 1, 1989).

[12] FARRELL, K. and R. T. King, Met. Trans., Vol. 4, 1223-1231, 1973.

[13] LAM, P.-S.; R.L. Sindelar, H.B. Peacock, Jr., "Vapor Corrosion of Aluminum Cladding Alloys and Aluminum-Uranium Fuel Materials in Storage Environments (U),” WSRC-TR-97-00120, 4/1/1997.

[14] FIELD, D. J., Oxidation of Aluminum and Its Alloys, Chapter 19, Aluminum Alloys - Contemporary Research and Applications, ed. by A. K. Vasudevan and R. D. Doherty, Vol. 31 Treatise on Materials Science and Technology, Academic Press, Inc. Boston, MA, 1989

[15] SINDELAR, R.L., P.S. Lam, M.R. Louthan, Jr., and N.C. Iyer, "Corrosion of Metals and Alloys in High Radiation Fields,” Materials Characterization, Vol. 43, pp. 147-157, 1999. 
[16] OPENSHAW, P.R. and L. L. Shreir, “Oxidation of Uranium-Aluminum Intermetallic Compounds,” Corrosion Science, 1963, Vol. 3 pp. 217 to 237.

[17] FISHER, D.L., and R.L. Sindelar, "Radiolytic Hydrogen Generation from Aluminum Oxyhydroxides,” to be published.

[18] ASTM C1553-08, Standard Guide for Drying Behavior of Spent Nuclear Fuel, ASTM International, 2008.

[19] SDD-45. System Design Description, INTEC IFSF Fuel Conditioning Station, 11/21/05.

[20] EDF-5063, Intact Aluminum Plate Fuel Drying Characteristics, 6/7/06.

[21] Presentations at IAEA Technical Meeting "Guideline of Good Practice for the Management and Storage of Research Reactor Spent Fuel”October 19-23 2009, Dounreay, Thurso, U.K., Mr Lubi Dimitrovski, Australian Nuclear Science and Technology Organisation (ANSTO) Manager, Waste Operations, Mr Jim Z.W. Lian, Research Reactor Fuel Development, Station E5, AECL — Chalk River Laboratories

[22]. EBNER, M.A., The Potential Pyrophoricity of BMI-SPEC and Aluminum Plate Spent Fuels Retrieved From Underwater Storage, INEL-96/0235. 
